\title{
Penerapan Teori Konstruktivisme untuk Meningkatkan Prestasi Belajar PKn Pada Siswa Kelas VI SD Negeri 1 Punjul Tulungagung
}

\author{
Sularmi $^{1}$ \\ ${ }^{1}$ SD Negeri 1 Punjul Tulungagung \\ Email: ${ }^{1}$ sularmi@gmail.com
}

\begin{tabular}{l}
\hline Tersedia Online di \\
\hline http://www.jurnal.unublitar.ac.id/ \\
index.php/briliant
\end{tabular}

Sejarah Artikel

Diterima pada 6 April 2018

Disetuji pada 9 April 2018

Dipublikasikan pada 13 Mei 2018

Hal. 165-174

\begin{tabular}{l}
\hline Kata Kunci: \\
\hline prestasi belajar, pkn, \\
konstruktivisme \\
\hline
\end{tabular}

DOI:

http://dx.doi.org/10.28926/briliant .v3i2.171

\begin{abstract}
Abstrak: Berdasarkan hasil observasi yang dilakukan di Kelas VI pada waktu pembelajaran Pendidikan Kewarganegaraan diperoleh hasil bahwa Prestasi belajar siswa kurang memuaskan. Untuk itu agar dapat meningkatkan prestasi belajar siswa dalam menyelesaikan soal tentang Nilai kebersamaan dalam proses perumusan Pancasila serta untuk tercapainya tujuan pembelajaran perlu diadakan perbaikan pembelajaran dengan menerapkan Teori Konstruktivisme. penerapan pembelajaran Nilai kebersamaan dalam proses perumusan Pancasila melalui Teori Konstruktivisme dapat meningkatkan Prestasi belajar siswa. Hal ini dibuktikan dengan adanya peningkatan Prestasi belajar siswa berdasarkan nilai post test per siklus dengan nilai di atas KKM yaitu persentase pada siklus I $66,7 \%$ dan pada siklus II $90,5 \%$.
\end{abstract}

Proses belajar mengajar guru, tidak harus terpaku dengan menggunakan satu metode atau strategi pembelajaran saja, seorang guru mampu menggunakan metode atau strategi pembelajaran yang bervariasi agar dalam kegiatan belajar mengajar tidak membosankan bagi siswa dan sesuai dengan tujuan yang ingin dicapai yaitu tercapainya peningkatan motivasi dan prestasi belajar (Slameto, 2003).

Selain itu, pembelajaran adalah usaha guru dalam membentuk perilaku siswa sesuai tujuan yang diinginkan dengan cara menyediakan lingkungan yang mendukung agar terjadi interaksi yang baik sesama siswa. Dengan kata lain pembelajaran diartikan sebagai suatu proses menciptakan lingkungan sebaikbaiknya agar terjadi kegiatan belajar mengajar yang berdaya guna. (Sugandi dan Haryanto 2003: 35). Pembelajaran pada hakikatnya merupakan proses komunikasi transaksional yang bersifat timbal balik, baik antara Guru dengan siswa, maupun antara siswa dengan siswa, untuk mencapai tujuan yang telah ditetapkan. (Susilana, 2008: 9)

Pendidikan kewarganegaraan dirumuskan secara luas untuk mencakup proses penyiapan generasi muda untuk mengambil peran dan tanggung jawab sebagai warganegara, dan secara khusus, peran pendidikan termasuk di dalamnya persekolahan, pengajaran dan belajar, dalam proses penyiapan warganegara tersebut. 
Pendidikan Kewarganegaraan yaitu pendidikan yang menyangkut status formal warga negara yang pada awalnya diatur dalaam Undang-Undang No.2 tahun 1949 (Ruminiati, 2008: 25). Undang - Undang ini berisi tentang diri kewarganegaraan dan peraturan tentang naturalisasi atau pemerolehan status sebagai warga negara Indonesia (Winaputra, dalam Ruminiati, 2008: 25).

Menurut Zamroni ( Tim ICCE, 2005: 7) pengertian pendidikan kewarganegaraaan adalah Pendidikan demokrasi yang bertujuan untuk mempersiapkan warga masyarakat berpikir kritis dan bertindak demokratis, melalui aktivitas menanamkan kesadaran kepada generasi baru, bahwa demokrasi adalah bentuk kehidupan masyarakat yang paling menjamin hak-hak warga masyarakat". Diharapakan dapat mempersiapkan peserta didik menjadi warga negara yang memiliki komitmen yang kuat dan konsisten untuk mempertahankan Negara Kesatuan Rebuplik Indonesia. Hakekat NKRI adalah negara kebangsaan modern.

Pendidikan Kewarganegaraan di Indonesia dapat diharapkan mempersiapkan peserta didik menjadi warga negara yang memiliki komitmen yang kuat dan konsisten untuk mempertahankan Negara Kesatuan Republik Indonesia. Hakikat negara kesatuan republik indonesia adalah negara kesatuan modern. Negara kebangsaan adalah negara yang pembentuknya didasarkan pada pembentukan semangat kebangsaan dan nasionalisme yaitu pada tekad suatu masyarakt untuk membangun masa depan bersama dibawah satu negara yang sama.walaupun warga masyarakaat itu berbeda-beda agama, ras, etnik, atau golongannya.

Dalam proses pembelajaran di kelas sering timbul masalah yang pada umumnya dialami oleh siswa. Masalah yang dihadapi siswa bersifat unik berbeda satu sama lain. Misalnya masalah dan kesulitan ataupun rendahnya prestasi belajar yang dialami siswa pada mata pelajaran Pendidikan Kewarganegaraan bisa terjadi karena berbagai faktor diantaranya. 1) Keterbatasan kemampuan, keadaan, minat dan motivasi diri siswa itu sendiri. 2) Situasi belajar di sekolah atau kelas dan kurangnya sarana dan prasarana. 3) Materi pelajaran yang kurang relevan dengan kebutuhan siswa. 4) Metode mengajar yang kurang bisa dipahami siswa bahkan kurangnya alat peraga dan alat bantu mengajar.

Apalagi mata pelajaran Pendidikan Kewarganegaraan menuntut kemampuan Guru untuk bisa membuat siswa mengerti dan memahami tentang materi yang diajarkan dengan tidak hanya membaca buku dan teori saja melainkan harus diterapkan dalam kehidupan sehari-hari, bermasyarakat dan berdaulat, agar siswa memiliki pengetahuan, keterampilan yang cerdas, terampil, berkarakter yang diamanatkan oleh Pancasila dan UUD 1945.

Berdasarkan hasil pengamatan dalam proses belajar mengajar dikelas, keadaan sekolah, dan melalui peninjauan bidang akademik dan non akademik, diperoleh hasil bahwa keadaan Sekolah Dasar Negeri 1 Punjul Kecamatan Karangrejo khususnya siswa kelas VI tahun ajaran 2015/2016 dalam pelajaran Pendidikan Kewarganegaraan belum menunjukkan prestasi belajar sesuai dengan KKM yang ditetapkan terutama pada nilai kebersamaan dalam proses perumusan Pancasila. Padahal, ditinjau dari keadaan fisik sekolah, yaitu ruang kelas VI sudah baik dan sesuai sebagai tempat berlangsungnya proses belajar mengajar. Pengamatan pada proses pembelajaran oleh peneliti dapat disimpulkan bahwa 
pelaksanaan proses belajar mengajar lah yang belum membuat siswa aktif belajar, sehingga kemampuan siswa belum tergali dengan maksimal.

Menurut Nana Sudjana (1989:28) belajar adalah proses yang diarahkan kepada tujuan, proses berbuat melalui berbagai pengalaman, melihat, mengamati dan memahami sesuatu. Oemar Hamalik (1999:37) berpendapat belajar adalah suatu proses perubahan tingkah laku siswa melalui interaksi dengan lingkungan. Pada ulangan harian Pendidikan Kewarganegaraan dengan nilai kebersamaan dalam proses perumusan Pancasila, di dapat rata-rata nilai sebesar 62,1 dari 21 siswa, padahal Kriteria Ketuntasan Minimalnya (KKM) telah ditentukan nilai sebesar 70. Dan hanya 7 siswa yang mendapat nilai di atas 70. Hal ini berarti, hanya 33,3\% dari siswa yang telah mencapai ketuntasan belajar, dan yang lainnya memiliki prestasi belajar yang rendah.

Berdasarkan hal tersebut, peneliti meminta bantuan kepada teman sejawat untuk meneliti kekurangan dari pembelajaran yang telah dilaksanakan. Dari hasil diskusi dengan teman sejawat ditemukan masalah-masalah dalam proses pembelajaran Pendidikan Kewarganegaraan yang menyebabkan menurunkan prestasi belajar adalah sebagai berikut: 1) Materi kurang dapat dikuasi siswa secara optimal. 2) Siswa belum dapat menyelesaikan soal nilai kebersamaan dalam proses perumusan Pancasila. 3) Melihat hasil ulangan harian siswa diatas, bisa dilihat jika penggunaan metode pembelajaran dalam pembelajaran Pendidikan Kewarganegaraan pada siswa kelas VI belum sesuai dan membuat siswa terlihat tidak antusias untuk belajar. 4) Pembelajaran dengan metode konvensional yaitu dengan menjelaskan materi dan siswa hanya melakukan perintah mengerjakan soal tanpa penanaman konsep pembelajaran yang kuat ternyata tidak efektif dalam proses peningkatan prestasi belajar siswa.

Setelah melihat hasil analisa di atas dan tukar pendapat dengan teman sejawat, maka untuk memperoleh prestasi belajar yang optimal, tidak hanya memerlukan suatu latihan yang terus menerus, tetapi terlebih dahulu siswa harus mengetahui inti dari materi yang dipelajarinya. Berdasarkan konsep yang mereka temukan sendiri di dalam proses pembelajaran, tentu siswa akan lebih bersemangat, dan aktif belajar serta berusaha mencari penyelesaian masalah yang diberikan oleh Gurunya dengan menggunakan kemampuannya sendiri.

Adanya semangat atau motivasi siswa dalam belajar dan konsep yang tertanam dengan baik, diharapkan siswa mampu menyelesaikan setiap tugas yang diberikan dengan prosedur yang benar, sehingga prestasi belajar yang diperoleh menjadi lebih baik dari semula serta terjadi peningkatan prestasi belajar siswa.

Oleh karena itu, demi memperbaiki berbagai masalah yang ada, peneliti memerlukan suatu solusi untuk mengatasi hambatan-hambatan yang terjadi. Akhirnya diputuskan dengan menggunakan Teori Konstruktivisme dalam pembelajaran Pendidikan Kewarganegaraan ini. Teori Konstruktivisme adalah teori yang memberikan keaktifan terhadap siswa untuk belajar menemukan sendiri kompetensi, pengetahuan atau teknologi, dan hal lain yang diperlukan guna mengembangkan dirinya sendiri..

Teori belajar tersebut berkenaan dengan kesiapan anak untuk belajar, yang dikemas dalam tahap perkembangan intelektual dari lahir hingga dewasa. Setiap tahap perkembangan intelektual yang dimaksud dilengkapi dengan ciri-ciri tertentu dalam mengkonstruksi ilmu pengetahuan. Misalnya, pada tahap sensori motor anak berpikir melalui gerakan atau perbuatan. Pengetahuan tidak bisa 
ditransfer dari guru kepada orang lain, karena setiap orang mempunyai skema sendiri tentang apa yang diketahuinya. Pembentukan pengetahuan merupakan proses kognitif di mana terjadi proses asimilasi dan akomodasi untuk mencapai suatu keseimbangan sehingga terbentuk suatu skema (jamak: skemata) yang baru. Seseorang yang belajar itu berarti membentuk pengertian atau pengetahuan secara aktif dan terus-menerus (Suparno, 1997).

Dari keterangan diatas dapatlah ditarik kesimpulan bahwa teori ini memberikan keaktifan terhadap manusia untuk belajar menemukan sendiri kompetensi, pengetahuan atau teknologi, dan hal lain yang diperlukan guna mengembangkan dirinya sendiri. Pembelajaran berdasarkan konstruktivisme memberikan kesempatan kepada siswa untuk mengungkapkan gagasan secara eksplisit dengan menggunakan bahasa siswa sendiri, berbagi gagasan dengan temannya, dan mendorong siswa memberikan penjelasan tentang gagasannya.

\section{METODE}

Dalam pelaksanaan Penelitian Perbaikan Pembelajaran ini yang akan menjadi subjek adalah seluruh siswa kelas VI Sekolah Dasar Negeri 1 Punjul Kecamatan Karangrejo Tulungagung tahun pelajaran 2015/2016 sebanyak 21 siswa yang terdiri dari 12 siswa putra dan 9 siswa putri.

Lokasi yang digunakan tempat penelitian adalah ruang kelas VI Sekolah Dasar Negeri 1 Punjul Kecamatan Karangrejo Tulungagung Tahun Pelajaran 2015/2016. Penelitian dilaksanakan pada semester 1, pada tanggal 6 Agustus 2015 sampai dengan 13 Agustus 2015. Setiap kali pertemuan membutuhkan waktu 80 menit dengan rincian $2 \times 40$ menit.

Berdasarkan variable yang diteliti dan tujuan yang hendak dicapai, mata metode penelitian yang digunakan adalah dengan teknik korelasi. Dengan berbagai metode yang digunakan peneliti, peneliti berupaya untuk meningkatkan prestasi belajar Pendidikan Kewarganegaraan terutama pembelajaran Pendidikan Kewarganegaraan tentang nilai kebersamaan dalam proses perumusan Pancasila siswa kelas VI SD Negeri 1 Punjul Kecamatan Karangrejo dengan menggunakan Teori Konstruktivisme.

Berdasarkan hasil pengidentifikasian dan penetapan masalah, peneliti kemudian mengajukan suatu solusi yang berupa penerapan Teori Konstruktivisme yang dapat dimanfaatkan Guru untuk digunakan sebagai metode pengajaran dalam pembelajaran Pendidikan Kewarganegaraan kelas VI SD Negeri 1 Punjul Kecamatan Karangrejo Tulungagung. Penelitian ini dilakukan dengan dua siklus, dimana masing-masing siklus dikenai perlakuan yang sejenis dengan bobot yang beda. Dibuat dua siklus dimaksudkan untuk memperbaiki system pengajaran yang dilaksanakan.

Adapaun ragam instrument penelitian tindakan kelas yang telah dipersiapkan yaitu, Rencana Pelaksaaan Pembelajaran sebagai instrument rencana pelaksanaan tindakan. Lembar observasi Guru sebagai instrument utama pengumpul data proses dan lembar observasi siswa, wawancara, angket dan catatan lapangan sebagai instrument pendukung pengumpul data proses. Selain itu juga terdapat instrument pengumpul data hasil, yang dapat dikumpulkan dari prestasi belajar berdasarkan soal-soal yang diberikan, serta ketrampilan siswa berdasarkan rubrik yang ada. 
Teknik analisis yang digunakan yaitu deskriptif persentase. Data hasil penelitian yang dianalisis meliputi rata-rata kelas, ketuntasan belajar individu dan ketuntasan belajar secara klasikal. Selanjutnya hasil analisis data diperoleh baik secara kualitatif (dengan kata-kata) dan kuantitatif (dengan grafik). Hasil ini diinterprestasikan dan disimpulkan untuk menjawab permasalahan yang ada.

Analisis data dari sumber-sumber informasi hasil penelitian di dapat dari: (1) Analisis Data Observasi, Data hasil observasi keterlaksanaan pembelajaran melalui Teori Konstruktivisme dan observasi aktivitas siswa dianalisis secara deskriptif untuk memberikan gambaran pelaksanaan pembelajaran dengan menggunakan Teori Konstruktivisme. (2) Analisis Data Wawancara, Hasil wawancara dengan siswa dianalisi secara deskriptif dengan lembar angket untuk mengetahui pendapat Guru dan siswa terhadap pembelajaran. (3) Analisis Data Tes, Berdasarkan hasil tes siswa, setiap soal diberi skor kemudian diperoleh nilai untuk setiap siswa.

\section{HASIL}

\section{Pra Tindakan}

Dari pengumpulan data, nilai ulangan harian tentang nilai kebersamaan dalam proses perumusan Pancasila, rata-rata nilai yang didapat hanya sebesar 62,1. Dari 21 siswa, hanya 7 siswa yang mendapat nilai di atas 70. Ini berarti hanya 33,3\% siswa yang telah mencapai ketuntasan belajar, karena Kriteria Ketuntasan Minimal (KKM) telah ditentukan sebesar 70.

Berdasarkan kondisi awal di atas, maka akan diterapkan Teori Konstruktivisme, sehingga siswa kelas VI SD Negeri 1 Punjul Kecamatan Karangrejo Tulungagung tahun pelajaran 2015/2016 dapat mengatasi kesulitan belajar tentang nilai kebersamaan dalam proses perumusan Pancasila. Tabel berikut adalah daftar frekuensi nilai ulangan harian Pendidikan Kewarganegaraan nilai kebersamaan dalam proses perumusan Pancasila siswa kelas VI SD Negeri 1 Punjul Kecamatan Karangrejo Tulungagung, dengan nilai KKM sebesar 70:

\section{Tabel 1 Daftar Nilai Ulangan Harian Kondisi Awal}

\begin{tabular}{|c|c|c|}
\hline Nilai & Frekuensi & Prosentase \\
\hline $0-40$ & 1 & $4,8 \%$ \\
\hline $41-69$ & 13 & $61,9 \%$ \\
\hline $70-100$ & 7 & $33,3 \%$ \\
\hline Jumlah & 21 & $100 \%$ \\
\hline
\end{tabular}

Dari tabel diatas dapat kita lihat terdapat 1 siswa atau $4,8 \%$ yang mendapat nilai antara $0-40$, ada 13 siswa atau $61,9 \%$ yang mendapat nilai antara $41-69$, dan ada 7 siswa atau 33,3\% yang mendapat nilai antara $70-100$. Dengan ketentuan nilai KKM 70, maka dapat disimpulkan jika pencapaian prestasi nilai 70 - 100 yang hanya 33,3\% merupakan prestasi yang rendah.

Selain itu, dari proses wawancara diperoleh kesimpulan bahwa siswa kurang berminat dalam melaksanakan kegiatan pembelajaran, serta dalam pembelajaran Guru lebih sering menggunakan ceramah sehingga siswa merasa jenuh dan bosan, akibatnya minat siswa untuk belajar Pendidikan 
Kewarganegaraan terutama pada nilai kebersamaan dalam proses perumusan Pancasila menjadi berkurang sehingga mempengaruhi hasil prestasinya.

Berdasarkan hasil data yang dikumpulkan, dapat dikemukakan dua hal pokok yang perlu diatasi, yaitu menumbuhkan minat siswa untuk belajar Pendidikan Kewarganegaraan dan memahamkan nilai kebersamaan dalam proses perumusan Pancasila dengan cara mengaktifkan siswa dalam kegiatan belajar mengajar dan meningkatkan prestasi belajar siswa dengan menerapkan Teori Konstruktivisme pada siklus 1 nanti dengan harapan prestasi belajar siswa dapat meningkat.

\section{Siklus 1}

Pelaksanaan pembelajaran, Guru masih menghadapi berbagai kendala, antara lain: (1) Masih ada kelompok yang bingung dalam mengikuti langkahlangkah yang tertera dalam lembar kegiatan. (2) Masih ada beberapa siswa yang belum aktif dalam pelaksanaan percobaan. (3) Ketika pelaksanaan diskusi, ada beberapa siswa yang tidak aktif menyampaikan pendapatnya. (4) Dalam menyimpulkan hasil percobaan, terdapat 3 (tiga) kelompok yang malu untuk presentasi, dan hanya terdapat 3 (tiga) siswa yang mengajukan pertanyaan.

Adapun prosentase hasil observasi dalam pelaksanaan percobaan pada siklus I dapat dilihat dari tabel 3 bawah ini. Perhitungan prosentase keberhasilan siklus I di bawah ini diskusikan juga dengan teman sejawat.

\section{Tabel 2 Prosentase Hasil Observasi Siklus I}

\begin{tabular}{|l|l|l|}
\hline No & Kegiatan Siswa & Prosentase \\
\hline 1 & Kelengkapan menyiapkan alat dan bahan percobaan & $33 \%$ \\
\hline 2 & Keruntutan langkah-langkah dalam pelaksanaan kegiatan percobaan & $40 \%$ \\
\hline 3 & Keaktifan siswa selama melaksanakan kegiatan percobaan & $66,7 \%$ \\
\hline 4 & Keaktifan siswa dalam mengutarakan pendapat saat berdiskusi & $55 \%$ \\
\hline 5 & Kesimpulan akhir sesuai percobaan & $48 \%$ \\
\hline
\end{tabular}

Hasil post test pada siklus pertama dapat menjadi perhitungan persentase peningkatan prestasi prestasi belajar siswa. Dengan acuan penilaian tetap berdasarkan nilai KKM yang telah ditetapkan yaitu paling sedikit siswa memperoleh nilai 70. Adapun rekapitulasi hasil test siklus I adalah sebagai berikut:

Tabel 3 Hasil Post Test Siklus Pertama

\begin{tabular}{|l|l|l|}
\hline No & Deskripsi & Nilai \\
\hline 1 & Jumlah Nilai & 1525 \\
\hline 2 & Rata-rata Hasil Post Test & 72,6 \\
\hline 3 & Jumlah siswa yang mendapat nilai diatas KKM (70) & 14 \\
\hline 4 & Presentase siswa yang mendapat nilai diatas KKM (70) & $66,7 \%$ \\
\hline 5 & Jumlah siswa yang mendapat nilai dibawah KKM (70 & 7 \\
\hline 6 & Presentase siswa yang mendapat nilai dibawah KKM (70) & $33,3 \%$ \\
\hline
\end{tabular}


Nilai rata-rata hasil post test, dapat dihitung dari : $\dot{X}=\frac{\sum x}{\sum N}$, Jadi $\dot{X}=$ $\frac{1525}{21}=72,6$. Nilai KKM $=70$. Jadi sudah ada peningkatan prestasi belajar, namun hanya sedikit. Rumus Ketuntasan Individu (prestasi belajar siswa) = $\underline{\sum \text { siswa yang mendapat nilai } \geq 70}$ siswa) $=\frac{14}{21} \times 100 \%=66,7 \%$

Esiswa $\quad$ x $100 \%$. Jadi, Ketuntasan Individu (prestasi belajar

Masing kurang dari indicator pencapaian siklus I sebesar $85 \%$ atau lebih. Maka dilanjutkan percobaan pembelajaran dengan Teori Konstruktivisme pada siklus II.

Tabel berikut adalah daftar frekuensi nilai post test siklus I Pendidikan Kewarganegaraan nilai kebersamaan dalam proses perumusan Pancasila dengan soal pengerjaan siswa kelas VI SD Negeri 1 Punjul Kecamatan Karangrejo Tulungagung setelah pembelajaran menggunakan Teori Konstruktivisme, dengan nilai minimal KKM sebesar 70:

Tabel 4 Daftar Nilai Ulangan Harian Siklus I

\begin{tabular}{|c|c|c|}
\hline Nilai & Frekuensi & Prosentase \\
\hline $0-40$ & 0 & $0.0 \%$ \\
\hline $41-69$ & 14 & $33,3 \%$ \\
\hline $70-100$ & 7 & $66,7 \%$ \\
\hline Jumlah & 21 & $100 \%$ \\
\hline
\end{tabular}

Dari tabel diatas dapat kita lihat terdapat 7 siswa atau 33,3\% yang mendapat nilai antara 41 - 69, dan 14 siswa atau 66,7\% yang mendapat nilai antara 70 - 100. Dengan ketentuan nilai KKM 70, dapat disimpulkan jika pencapaian prestasi nilai 70 - 100, maka prestasi belajar siswa telah meningkat dari $35 \%$ menjadi $66,7 \%$. Namun karena belum mencapai target indicator pencapaian siklus I sebesar $85 \%$ atau lebih, maka akan dilanjutkan ke Siklus II.

\section{Siklus II}

Dalam pelaksanaan proses pembelajaran, Guru telah melaksanakan perbaikan dari siklus I, siswa sudah mengalami kemajuan dan pelaksanaan-pun telah berjalan baik. Namun Guru menemukan masalah baru dalam pelaksanaan siklus II, yaitu: (1) Siswa belum memahami cara konsep presentasi dengan baik. Namun diantisipasi oleh peneliti dengan memberikan pendekatan dan pemahaman kepada siswa cara membuat konsep presentasi dengan benar. (2) Masih terdapat 3-4 siswa yang malu dalam presentasi dan kurang aktif dalam diskusi kelompok.

Adapun prosentase hasil observasi dalam pelaksanaan percobaan pada siklus II dapat dilihat dari tabel bawah ini. Perhitungan prosentase keberhasilan siklus II di bawah ini diskusikan juga dengan teman sejawat.

Tabel 5 Prosentase Hasil Observasi Siklus II

\begin{tabular}{|l|l|l|}
\hline No & Kegiatan Siswa & Prosentase \\
\hline 1 & Kelengkapan menyiapkan alat dan bahan percobaan & $70 \%$ \\
\hline 2 & Keruntutan langkah-langkah dalam pelaksanaan kegiatan percobaan & $85 \%$ \\
\hline
\end{tabular}

171 BRILIANT: Jurnal Riset dan Konseptual Volume 3 Nomor 2, Mei 2018 


\begin{tabular}{|l|l|l|}
\hline 3 & Keaktifan siswa selama melaksanakan kegiatan percobaan & $87 \%$ \\
\hline 4 & Keaktifan siswa dalam mengutarakan pendapat saat berdiskusi & $85 \%$ \\
\hline 5 & Kesimpulan akhir sesuai percobaan & $82 \%$ \\
\hline
\end{tabular}

Hasil post test pada siklus kedua dapat menjadi perhitungan persentase peningkatan prestasi belajar siswa. Dengan acuan penilaian tetap berdasarkan nilai KKM yang telah ditetapkan yaitu paling sedikit siswa memperoleh nilai 70 . Adapun rekapitulasi hasil test siklus II adalah sebagai berikut:

Tabel 6 Hasil Post Test Siklus Kedua

\begin{tabular}{|l|l|l|}
\hline No & Deskripsi & Nilai \\
\hline 1 & Jumlah Nilai & 1760 \\
\hline 2 & Rata-rata Hasil Post Test & 83,8 \\
\hline 3 & Jumlah siswa yang mendapat nilai diatas KKM (70) & 19 \\
\hline 4 & Presentase siswa yang mendapat nilai diatas KKM (70) & $90,5 \%$ \\
\hline 5 & Jumlah siswa yang mendapat nilai dibawah KKM (70 & 2 \\
\hline 6 & Presentase siswa yang mendapat nilai dibawah KKM (70) & $9,5 \%$ \\
\hline
\end{tabular}

Nilai rata-rata hasil post test, dapat dihitung dari : $\dot{X}=\overline{\sum_{N}}$, Jadi $\dot{X}=$ $\frac{1760}{21}=83,8$. Nilai KKM $=70$. Jadi sudah ada peningkatan prestasi belajar yang signifikan. Rumus Ketuntasan Individu (prestasi belajar siswa) = Esiswa yang mendapat nillai $\geq 70$ Esiswa
siswa) $=\frac{19}{21} \times 100 \%=90,5 \%$

Telah mencapai indicator pencapaian siklus II sebesar $85 \%$ atau lebih. Maka tidak perlu dilanjutkan percobaan pembelajaran dengan Teori Konstruktivisme pada siklus III.

Tabel berikut adalah daftar frekuensi nilai post test siklus II Pendidikan Kewarganegaraan dengan nilai kebersamaan dalam proses perumusan Pancasila siswa kelas VI SD Negeri 1 Punjul Kecamatan Karangrejo Tulungagung setelah pembelajaran menggunakan Teori Konstruktivisme siklus II, dengan nilai minimal KKM sebesar 70:

Tabel 7 Daftar Nilai Ulangan Harian Siklus II

\begin{tabular}{|l|l|l|}
\hline Nilai & Frekuensi & Prosentase \\
\hline $0-40$ & 0 & $0.0 \%$ \\
\hline $41-69$ & 2 & $9,5 \%$ \\
\hline $70-100$ & 19 & $90,5 \%$ \\
\hline Jumlah & 21 & $100 \%$ \\
\hline
\end{tabular}

Dari tabel diatas dapat kita lihat terdapat 2 siswa atau 9,5\% yang mendapat nilai antara $41-69$, dan 19 siswa atau $85 \%$ yang mendapat nilai antara 70 - 100. Dengan ketentuan nilai KKM 70, dapat disimpulkan jika pencapaian prestasi nilai 70 - 100, maka prestasi belajar siswa telah meningkat dari $66,7 \%$ menjadi 90,5\%. Dengan 90,5\% maka telah tercapai indicator pencapaian siklus II sebesar yang $85 \%$ atau lebih, maka tidak perlu dilanjutkan ke Siklus III. 


\section{PEMBAHASAN}

Berdasarkan hasil pelaksanaan pada siklus I, II dapat dinyatakan bahwa terjadi peningkatan kualitas pembelajaran yang tampak dan perolehan hasil evaluasi dan keaktifan siswa. Dari tabel 2 siklus I hasil observasi menunjukkan, prosentase keberhasilan kelengkapan menyiapkan alat dan bahan percobaan 33\%, prosentase keruntutan langkah-langkah yang ditempuh dalam pelaksanaan percobaan $40 \%$, prosentase keaktifan siswa dalam melaksanakan kegiatan percobaan $66,7 \%$, prosentase keaktifan siswa dalam mengutarakan pendapat saat berdiskusi $55 \%$ dan prosentase hasil penarikan kesimpulan akhir sesuai percobaan $48 \%$.

Berdasarkan tabel 5 siklus II hasil observasi menunjukkan, prosentase keberhasilan metode kelengkapan menyiapkan alat dan bahan percobaan siswa yang disiapkan $70 \%$, prosentase keruntutan langkah-langkah yang ditempuh dalam pelaksanaan percobaan $85 \%$, prosentase keaktifan siswa dalam melaksanakan kegiatan percobaan $87 \%$, prosentase keaktifan siswa dalam mengutarakan pendapat saat berdiskusi $85 \%$ dan prosentase hasil penarikan kesimpulan akhir sesuai percobaan $82 \%$.

Dapat kita lihat adanya prosentase kenaikan nilai Pendidikan Kewarganegaraan mulai dari kondisi awal pra tindakan, diketahui baru 7 siswa atau 33,3\% yang mengalami ketuntasan belajar dan mendapatkan nilai sesuai dengan KKM. Hasil evaluasi siklus I menunjukkan baru 14 siswa atau 66,7\% yang mengalami ketuntasan belajar dan mendapat nilai sama dengan atau di atas KKM yaitu 70. Hal itu menunjukkan bahwa pelaksanaan siklus I belum mencapai keberhasilan, karena indicator pencapaian adalah sebesar $85 \%$ atau lebih. Siklus II menunjukkan ada 19 siswa atau 90,5\% dari 21 siswa yang mengalami ketuntasan belajar. Sehingga peneliti menyimpulkan bahwa pada siklus II ini peneliti telah mencapai keberhasilan dari penelitian tindakan kelas yang telah dilakukan.

Ketika peneliti melaksanakan siklus I, peneliti mengalami berbagai kendala antara lain siswa belum memahami rumusan Pancasila dengan baik. Masih ada kelompok yang bingung dalam mengikuti langkah-langkah yang tertera dalam lembar kegiatan. Masih ada beberapa siswa yang belum aktif dalam pelaksanaan percobaan. Ketika pelaksanaan diskusi, ada beberapa siswa yang tidak aktif menyampaikan pendapatnya. Dalam menyimpulkan hasil percobaan, terdapat 3 (tiga) kelompok yang malu untuk presentasi, dan hanya terdapat 3 (tiga) siswa yang mengajukan pertanyaan.

Peneliti kemudian melaksanakan siklus II sebagai perbaikan siklus I, sebelum pelaksanaan siklus II ini peneliti mengganti rencana pembelajaran Teori Konstruktivisme baru yaitu dengan membuat konsep presentasi proses perumusan Pancasila. Dalam pelaksanaan percobaan, peneliti senantiasa memberi bimbingan untuk siswanya dalam melaksanakan langkah-langkah sesuai lembar kegiatan. Peneliti pun memberi bimbingan siswa saat berdiskusi untuk menarik kesimpulan. Dengan adanya motivasi guru berupa reward, siswa telah terlihat aktif dalam kegiatan pembelajaran dalam melaksanakan percobaan, presentasi di depan kelas dan berdiskusi menarik kesimpulan. Meskipun ada kendala yaitu Siswa belum memahami cara konsep presentasi dengan baik, namun dengan hasil prestasi belajar yang dicapai dapat disimpulkan bahwa penelitian tindakan kelas dari siklus II ini telah berhasil. 
Berdasarkan hasil observasi dan pelaksanaan siklus I dan II juga dapat kita amati adanya perubahan kenaikan prosentase dalam menyiapkan alat dan bahan, keruntutan langkah-langkah siswa dalam melaksanakan percobaan, keaktifan siswa dalam melaksanakan kegiatan percobaan, keaktifan siswa ketika berdiskusi dan hasil akhir atau simpulan yang diperoleh dari hasil kegiatan diskusi.

\section{KESIMPULAN}

Berdasarkan hasil penelitian tindakan kelas yang telah dilaksanakan dalam 2 siklus dengan menerapkan Teori Konstruktivisme dalam pembelajaran Pendidikan Kewarganegaraan pada siswa kelas VI SD Negeri 1 Punjul Kecamatan Karangrejo Tulungagung, dapat dibuat kesimpulan sebagai berikut: Penerapan Teori Konstruktivisme dapat meningkatkan prestasi belajar Pendidikan Kewarganegaraan siswa kelas VI SD Negeri 1 Punjul Kecamatan Karangrejo Tulungagung.

\section{SARAN}

Berdasarkan hasil penelitian, maka ada beberapa saran yang dapat dipergunakan sebagai bahan pertimbangan dan sebagai bahan uraian penutup penelitian tindakan kelas ini, antara lain: (1) Bagi Guru, Hendaknya mempersiapkan secara cermat perangkat pendukung pembelajaran dan fasilitas belajar yang diperlukan, karena sangat mempengaruhi efektivitas dan efisiensi pembelajaran yang pada akhirnya berpengaruh pada proses dan prestasi belajar Pendidikan Kewarganegaraan siswa. Guru juga harus memahami dan memvariasikan metode yang sesuai materi yang dapat digunakan dalam proses pembelajaran, sehingga siswa tidak merasa bosan. (2) Bagi Siswa, Hendaknya ikut berperan aktif dalam proses pembelajaran, selalu mengerjakan tugas-tugas yang diberikan guru dan meningkatkan usaha belajar sehingga dapat memperoleh prestasi yang diharapkan. (3) Bagi Sekolah, Hendaknya mengupayakan pengadaan berbagai media pembelajaran Pendidikan Kewarganegaraan untuk kelas rendah, baik bantuan maupun swadaya sekolah, sehingga lebih menunjang dalam penanaman konsep-konsep Pendidikan Kewarganegaraan secara lebih nyata sekaligus meningkatkan aktivitas belajar siswa.

\section{DAFTAR RUJUKAN}

Hamalik, O. 2004. Proses Belajar Mengajar. Jakarta : Bumi Aksara.

Ruminiati. 2008. Pengembangan Pendidikan Kewarganegaraan. Jakarta:

Departemen Pendidikan Nasional

Sudjana, N. 1989. Penelitian dan Penilaian Pendidikan. Bandung : Sinar Baru.

Tim ICCE. 2005. Pendidikan Kewargaan: Demokrasi, Hak Asasi Manusia dan Masyarakat Madani. Jakarta: Prenada Media.

Winataputra, U.S. 1995. Teori Belajar dan Pembelajaran. Bandung: Rosda Karya. 